\title{
Clinical Skills Abilities Development During COVID-19 Pandemic in Mexico City
}

Lourdes Adriana Medina-Gaona. ${ }^{1}$

\section{The Experience}

It was February 29, 2020, when the first 4 cases of COVID-19 were reported in Mexico.' It did not take long for this country of approximately 130 million people ${ }^{2}$ to enter a critical stage of this pandemic. By May, Mexico was already in the top 10 countries in number of deaths due to COVID-19. ${ }^{3}$ Despite the ongoing efforts of the Mexican government and citizens, it has become hard to reduce the rapid spreading of this virus. As a result, students of all grades were forced to study at home, including medical students. In Mexico, training of doctors takes place in the classroom for most of the first two years, taking courses such as anatomy, physiology, biochemistry, to name a few. Nevertheless, the subsequent years are considered critical for the future healthcare worker in developing clinical skills, not only learning to carry out several procedures, but also communication, establishing the patient history, and physical exam competencies. This step is crucial for the early development of skills to help foster a satisfactory doctor-patient relationship. ${ }^{4}$ Before the pandemic, Mexican students went to hospitals to observe and learn how to interact and build confidence with patients. When COVID-19 reached Mexico, medical schools decided to stop sending medical students to the hospital, but continued online learning, ultimately ending the opportunity for patient interaction.

As a $4^{\text {th }}$ year medical student in Mexico City, this sudden change was a particular challenge for me as I was starting to develop clinical skills that had to be practiced in simulation laboratories. COVID-19 brought us a new barrier, the development of empathy through a computer, not seeing the person face to face, doing semiology correctly, by observation, palpation, percussion, and auscultation, was lost. Our doctors have never lived this situation and teaching clinical skills through a computer, seemed impossible.

There is no doubt that the learning of medicine, thanks to technology, has been changed, as compared to 50 years ago. New tendencies of practicing with robots and simulations have become an amazing tool to avoid the use of animals or human bodies to learn anatomy or different procedures. For example, Tecnológico de Monterrey started in 2018 to implement a center of clinical simulation, this space allows students to interact with medical equipment. Doctor Rios, director of this center, explained that these places allow participants to complete several procedures without putting patients in danger. ${ }^{5}$ Despite all these advancements, physical examination training remains a challenge, even more in times of pandemic. Doctors could argue that it may not be necessary to examine the patient due to existing technology that could give us a precise diagnosis. To this argument, we could say that human trust has to be won by the doctor, not only to give the best treatment available but also to be able to respect the human aspect of medicine and take care of a person, not a disease. ${ }^{6}$ In Mexico, according to the National Commission for Medical Arbitration (Comisión Nacional de Arbitraje Médico, CONAMED) in 2015, 11,529 complaints to doctors were submitted, of which 2,516 were due to the doctor-patient relationship.? These doctors had a chance to learn in person; what is going to happen with those trained in pandemic times?

A teacher of mine told us once "Technological imaging or any other technology should be used only to confirm a diagnosis that you already have in mind, thanks to a good semiology and physical examination". This way of thinking, especially in a country, where resources are limited, is one of the main tools used by clinicians to came with a correct diagnosis, avoid misusing limited resources, and provide optimal treatment. ${ }^{8-9} \mathrm{It}$ is of great concern for my generation that these skills have not been developed. How can we gain the trust of people? Clinical skills are part of medical training and so new solutions have emerged through the pandemic.

In my experience, our school has developed an online simulated medical consult, where the clinical educator acts as a standardized patient, and we took the history. In my opinion, this was a great opportunity to develop a skill to recognize symptoms and practice history taking, nevertheless, signs may be missed. Our generation has learned to adapt and use the new technologies. COVID-19 is a new opportunity for medical schools and students to develop new ways to practice clinical skills, including doctor-patient interaction through different platforms. Another option for simulating teaching platforms is virtual reality, an option that is still under development. ${ }^{10}$

Technologies are required and can be used in the whole medical career. Their level of complexity should be tailored to each year or stage of training. In 2014, a survey was done among medical students to know their perception about the learning through technological devices." Most had perceived usefulness of different tools for learning nevertheless, $3^{\text {rd }}$-year students agreed that clinical skills could be affected with that type of training. In my perspective, after learning the theory in the first year, practicing based on it becomes essential to start understand better those concepts and contextualize them in everyday practice. The use of smartphones has become one of the most important tools for learning in several countries. Technology brings us the possibility of flexible learning. The development of new tools, by the support of other disciplines such as computer and engineering, has to be done for medical students to develop the ability of building trust, empathy, listening, observation, and others, all to give the best medical attention to our future patients.

1 Medical Student, Instituto Tecnológico y de Estudios Superiores de Monterrey, Mexico City Campus.

About the Author: Lourdes Adriana Medina is currently a 4th year medical student of a 7-year total program. She published in 2018 an original article in the International Journal of Medical Students and worked in summer programs in Instituto Nacional de Ciencias Médicas y Nutrición Salvador Zubirán researching on diabetes.

Editor: Francisco Javier Bonilla-Escobar 


\section{References}

1. Mexican Government. Coronavirus. Available from: https://coronavirus.gob.mx/. Last updated June 10, 2020; cited June 10, 2020. Spanish

2. World Bank. Population Total Mexico. Available from: https://data.worldbank.org/indicator/SP.POP.TOTL?locations=MX. Last updated 2018; cited June 102020

3. World Health Organization (WHO). Coronavirus Diseases. Available from: https://covid 19. who.int/?gclid=CjoKCQjwiYL3BRDVARIsAF9E4GcKIZ2vlXZkS3mrjLA8 oWECgNPQkgIT4_S-8CXVSixGVOSAXz]w3m8aApgvEALw_wCB. Last updated June 10 2020; cited June 10, 2020

4. Coold SD, Lipkin M, Jr. The Doctor-Patient Relationship: Challenges, Opportunities, and Strategies. J Gen Intern Med. 1999 Jan; 14(Suppl 1): S26-S33

5. Monterrey Technological Institute. The future is here: medical students practice with robots. Available from: https://tec.mx/es/noticias/monterrey/salud/elfuturo-llego-alumnos-de-medicina-practican-revisiones-en-robots. Last updated July 16 2018; cited June 10 2020. Spanish.

6. Asif T, Mohiuddin A, Hasan B, Pauly RR. Importance of Thorough Physical Examination: A Lost Art. Cureus. 2017 May 2;9(5):e1212.
7. National Commission for Medical Arbitration. Characteristics of complaints attended by the National Commission for Medical Arbitration. Available from: http://www.conamed.gob.mx/gobmx/boletin/pdf/boletin6/caracteristicas_queja S.pdf. Last updated 2015; cited June 10, 2020. Spanish.

8. Olivero R. Barráez C. [Importance of medical semiology in the acquisition of skills for the doctor]. Salus. 2011;15(3):31-36. Spanish.

9. New York Times. "It's not the virus". The shortage in Mexican hospitals also kill us". Available from: https://www.nytimes.com/es/2020/05/28/espanol/americalatina/mexico-hospitales-coronavirus.html. Last updated May 28, 2020; cited June 10, 2020. Spanish.

10. Pacheco Carrillo AM. The Utility of Online Resources in Times of COVID-19: A Mexican Medical Student Point of View. Int J Med Students. 2020 Jan-Apr;8(1):589.

11. Han $\mathrm{H}$, Nelson E, Wetter N. Medical students' online learning technology needs Clin Teach. 2014 Feb;11(1):15-9.

\section{Acknowledgments}

None.

Conflict of Interest Statement at Funding

The Authors have no funding, financial relationships or conflicts of interest to disclose.

Author Contributions

Conceptualization, Writing - Original Draft Preparation, at Writing - Review at Editing: LAMG.

Cite as:

Medina-Gaona LA. Clinical Skills Abilities Development During COVID-19 Pandemic in Mexico City. Int J Med Students. 2020 May-Aug;8(2):175-6.

This work is licensed under a Creative Commons Attribution 4.0 International License

ISSN 2076-6327

This journal is published by the University Library System, University of Pittsburgh as part of the Digital Publishing Program and is co-sponsored by the University of Pittsburgh Press. 